\title{
PENINGKATAN KEMAMPUAN MENULIS PUISI DENGAN TEKNIK AKROSTIK
}

\author{
Dwi Triswanto, Gigit Mujiyanto, Laili Ivana \\ Universitas Muhammadiyah Malang \\ dwitriswanto96@gmail.com
}

\begin{abstract}
This classroom action research aims to describe the results and learning process of writing poetry by looking at the building elements using an acrostic technique. This research consists of two cycles. The technique used to analyze data is quantitative and qualitative descriptive. The subject of this research is Class X Students of SMA Negeri 7 Malang. The results of the study found that (1) learning completeness showed an increase of $12.75 \%$ and (2) the results of students' writing learning showed an increase from the average value of $67,7 \%$ in the first cycle to 80.05 in the second cycle. Based on these results the use of the acrostic technique is recommended for learning to write poetry in high school.
\end{abstract}

Keywords: acrostic technique ; poetry ; writing.

Abstrak: Penelitian tindakan kelas ini bertujuan untuk mendeskripsikan hasil dan proses
pembelajaran menulis puisi dengan memerhatikan unsur pembangunya menggunakan teknik
akrostik. Penelitia ini terdiri dari dua siklus. Teknik yang digunakan untuk menganalisis data
adalah deskriptif kuantitatif dan kualitatif. Subjek penelitian ini ialah Siswa Kelas X SMA Negeri
7 Malang. Hasil penelitian menemukan bahwa (1) ketuntasan pembelajaran menunjukkan
peningkatan sebesar $12,75 \%$ dan $(2)$ hasil pembelajaran menulis siswa menunjukkan
peningkatans dari nilai rata-rata $67,7 \%$ pada siklus pertama meningkat menjadi 80,05 pada
siklus kedua. Berdasarkan hasil tersebut penggunaan teknik akrostik direkomendasikan untuk
pembelajaran menulis puisi di SMA.

Kata Kunci: teknik akrostik; puisi; menulis.

Permalink/DOI: http:/ /dx.doi.org/10.15408/dialektika.v5i1.6295 


\section{Pendahuluan}

Bahasa merupakan sebuah sistem lambang bunyi yang arbitrer dan secara konvensional disepakati oleh penggunanya sebagai alat untuk berkomunikasi, bekerja sama, dan mengidentikasi diri. ${ }^{1}$ Untuk mengoptimalkan fungsi-fungsi bahasa tersebut, seorang penutur bahasa harus menguasai empat keterampilan bahasa, di antaranya: Keterampilan menyimak (listening skills), keterampilan berbicara (speaking skills), keterampilan membaca (reading skills), dan keterampilan menulis (writing skills). Berdasarkan definsi tersebut dapat disimpulkan bahwa kemampuan atau keterampilan seseorang adalah berbahasa sangat berkaitan erat dengan optimalisasi fungsi-fungsi bahasa di dalam masyarakat yang dapat ia manfaatkan. ${ }^{2}$

Menulis merupakan keterampilan berbahasa yang memiliki tataran tertinggi. Hal ini disebabkan untuk menguasai keterampilan menulis, seorang penulis harus telah melewati atau memiliki penguasaan yang cukup terhadap keterampilan bahasa yang lain. ${ }^{3}$ Peningkatan keterampilan bahasa terutama menulis telah dilakukan melalui dunia pendidikan khususnya pembelajaran bahasa Indonesia. Salah satu tujuan mata pelajaran Bahasa Indonesia di sekolah menurut Atzamaki adalah agar peserta didik menikmati dan memanfaatkan karya sastra untuk memperluas wawasan, budi pekerti, serta meningkatkan pengetahuan dan kemampuan berbahasa, dan menghargai dan membanggakan sastra Indonesia sebagai khazanah budaya dan intelektual manusia Indonesia. Dengan demikian, sastra merupakan salah satu bagian yang tidak terpisahkan dari pengajaran Bahasa Indonesia yang tercantum dalam kurikulum. ${ }^{4}$

Penggunaan karya sastra sebagai alat untuk mencapai tujuan pembelajaran sangatlah diperluakan. Untuk mencapai tujuan pendidikan yang menekankan keseimbangan dimensi rohani dan jasmani, maka nilai-nilai yang terkandung dalam sastra dapat memperkaya dimensi-dimensi tersebut. Dalam

\footnotetext{
${ }^{1}$ Abdul Chaer, Linguistik Umum, (Jakarta: Rineka Cipta, 2012), h. 17.

${ }^{2}$ Fabio Testy Ariance Loren, Pemakaian Media Pembelajaran Keterampilan Menyimak dalam Pembelajaran Bahasa Indonesia bagi Penutur Asing, Lingua Didaktika: Jurnal Bahasa dan Pembelajaran Bahasa, Vol. 11, No.1.

3 Ahmad Bahtiar, dkk., Khazanah Bahasa: Memaknai Bahasa Indonesia dengan Baik dan Benar. (Bogor: In Media, 2019), h. 28.

4 Atmazaki, Mengungkap Masa Depan: Inovasi Pembelajaran Bahasa Indonesia dalam Konteks Pengembangan Karakter Cerdas. (Makalah. Padang: UNP, 2013), h.21
} 
konteks inilah sastra berpotensi sebagai pemancar berbagai nilai dan menjadi sumber pengilhaman tentang kebajikan (virtue) dan kebijakan.

Berdasarkan paparan tersebut, pengajaran sastra apabila dilakukan dengan teknik-teknik yang tepat akan memberikan dampak yang menyeluruh pada kompetensi yang dikuasi oleh siswa, terutama dalam pembentukan watak dan karakter siswa. Menulis puisi dengan memperhatikan unsur pembangunnya merupakan salah satu kompetensi dasar yang ditetapkan dalam pengajaran Bahasa Indonesia SMA kelas X. Melalui kompetensi ini, siswa diharapkan dapat mengungkapkan pikiran dan perasaan dalam puisi. Melalui puisi siswa diharapkan juga dapat menyalurkan pikiran dan perasaan secara estetik, termasuk menyampaikan kritik sosial. ${ }^{6}$

Pengajaran sastra telah ditetapkan dalam kurikulum, tetapi masih ditemukan kasus siswa yang kesulitan dalam mengeksplorasi dan menuangkan idenya. Dilihat dari model yang sering digunakan oleh guru, sebenarnya sudah cukup inovatif dengan menggunakan yang kooperatif. Namun, kemampuan menulis puisi siswa masih mengalami kendala. Kendala tersebut ditemukan oleh peneliti ketika melakukan studi pendahuluan di SMA Negeri 7 malang. Kedalakendala yang ditemui oleh peneliti ialah (1) minimnya kosakata yang dimiliki siswa, sehingga tidak dapat memilih diksi yang tepat untuk mengembangkan ide yang dimiliki menjadi sebuah puisi, (2) siswa merasa kesulitan dalam menumukan ide, (3) siswa cenderung terpaku dengan pembuatan judul terlebih dahulu ketika membuat sebuah puisi, hal ini justru menghambat kreativitas siswa untuk mengembangkan puisinya. Kendala-kendala tersebut merupakan kendala teknis yang dialami oleh siswa. Selain kendala teknis tersebut, para siswa juga belum memiliki penguasaan yang baik mengenai konsep puisi. Oleh karena itu, temuan-temuan tersebut dijadikan faktor yang melatarbelakangi penelitian ini.

Untuk menghadapi masalah siswa yang kurang mampu dalam menulis puisi, guru perlu menggunakan model, metode, maupun teknik yang tepat. Terdapat banyak model, metode, maupun teknik yang bisa dipilih. Dalam penelitian ini penulis menggunakan teknik akrostik sebagai pemecahan masalah berdasarkan observasi di kelas. Teknik akrostik dirasa sangat cocok digunakan pada teknik menulis puisi dikalangan para siswa. Karena kesederhanaannyalah

\footnotetext{
${ }^{5}$ Nurgiyantoro, B. \& A. Efendi, Prioritas Penen-tuan Nilai Pendidikan Karakter dalam Pembelajaran Sastra Remaja. (Cakrawala Pendidikan, 32 (3), 2013), h. 383.

${ }^{6}$ Syihaabul Hudaa, Optimalisasi Bahasa: Penggunaan Bahasa yang Baik, Logis, dan Santun di Media Massa, Jurnal Dialektika, Vol. 5, No. 1.
} 
teknik ini dipilih peneliti sebagi jalan keluar permasalahan yang dihadapi oleh siswa.

Keefektifan penggunaan teknik akrostik telah dibuktikan para penelitipeneliti terdahulu, yakni Herawati yang melakukan penelitian eksperimen dengan menggunakan teknik akrostik. Hasil penelitiannya menunjukkan bahwa teknik akrostik efektif digunakan dalam pembelajaran puisi. Hal ini dilihat dari temuan data mengenai kemampuan menulis puisi siswa yang lebih tinggi ketika menggunakan teknik akrostik dibandingkan siswa yang tidak menggunakan teknik akrostik. ${ }^{7}$ Al-Hajj dalam penelitiannya juga menemukan bahwa penggunaan strategi akrostik dalam pembelajaran menulis puisi dapat menunjukkan hasil positif. Hasil-hasil penelitian tersebut mengindikasikan bahwa teknik akrostik merupakan salah satu teknik yang andal dan dapat digunakan untuk meningkatkan keterampilan siswa menulis puisi. Hasil itu menjadi dasar pelaksanaan penelitian tindakan ini. ${ }^{8}$

Subjek penelitian pada penelitian ini adalah seorang guru bahasa Indonesia dan siswa kelas X SMP Negeri 7 Malang dengan jumlah siswa yang terdiri atas 40 orang siswa. Data penelitian berupa data proses dan hasil pembelajaran. Data penelitian diperoleh melalui observasi, wawancara, dan evaluasi tes dari setiap tindakan pembelajaran menulis puisi dengan menggunakan teknik akrostik. Data proses pembelajaran ini berkaitan dengan penerapan teknik akrostik dalam pembelajaran menulis puisi. Data tersebut diperoleh berdasarkan hasil observasi terhadap kegiatan guru dan siswa selama proses pembelajaran menulis puisi berlangsung. Selain itu, data juga diperoleh dari hasil wawancara ter-hadap siswa untuk mengetahui tanggapan mereka setelah mengikuti pembelajaran menulis puisi dengan teknik akrostik. Selanjutnya, data hasil pembelajaran meliputi hasil unjuk kerja dan evaluasi tes yang diperoleh dari hasil menulis puisi dengan menggunakan teknik akrostik.

Teknik yang digunakan untuk menganalisis data penelitian ini adalah teknik analisis deskriptif. Teknik deskriptif digunakan untuk menggambarkan perubahan sikap dan perilaku siswa dan guru dalam proses pembelajaran menulis pui-si melalui teknik akrostik dan mengacu pada data nontes yang berupa observasi dan wawancara. Teknik ini juga digunakan untuk menganalisis hasil unjuk kerja menulis puisi dan evaluasi tes siswa di setiap siklus.

\footnotetext{
${ }^{7}$ Herawati. 2010. Penerapan Penggunaan Strategi Akrostik dalam Pembelajaran Menulis Puisi Siswa Kelas VIII SMP Negeri 1 Bontomatene Kabupaten Selayar. Skripsi. Makassar: FBS UNM.

${ }^{8}$ Al-Hajj, I, Strategi Menulis Puisi Akrostik sebagai Upaya Meningkatkan Keterampilan Menulis Puisi Siswa Kelas VII SMPN 2 Kendari. Tesis. Makassar: UNM, 2015
} 


\section{Metode}

Jenis penelitian ini ialah penelitian tindakan kelas (classrooom action research). Mekanisme pelaksanaan penelitian ini dilakukan dalam dua siklus. Sesuai dengan tahapan penelitian tindakan kelas, terdapat empat tahapan, yaitu tahap perencanaan, pelaksanaan, observasi, dan refleksi. Penelitian yang dilakukan merupakan penelitian tindakan kelas yang berpola terintegrasi. Dikatakan terintegrasi karena sebelum melaksanakan tindakan diadakan diskusi dengan guru kelas untuk menyamakan persepsi.

Subjek penelitian ini ialah seorang guru Bahasa Indonesia dan siswa kelas X SMA Negeri 7 Malang dengan jumlah siswa yang terdiri atas 40 orang siswa. Data penelitian berupa data proses dan hasil pembelajaran. Data tersebut didapatkan melalui observasi, wawancara, dan evaluasi tes dari setiap tindakan pembelajaran menulis puisi dengan menggunakan teknik akrostik. Data proses pembelajaran ini berkaitan dengan penerapan teknik akrostik dalam pembelajaran menulis puisi. Data tersebut diperoleh berdasarkan hasil observasi terhadap kegiatan guru dan siswa selama proses pembelajaran menulis puisi berlangsung. Selain itu, data juga diperoleh dari hasil wawancara terhadap siswa untuk mengetahui tanggapan mereka setelah mengikuti pembelajaran menulis puisi dengan teknik akrostik. Selanjutnya, data hasil pembelajaran meliputi hasil unjuk kerja dan evaluasi tes yang diperoleh dari hasil menulis puisi dengan menggunakan teknik akrostik.

Teknik analisis data yang digunakan ialah teknik analisis des-kriptif. Teknik deskriptif digunakan untuk menggambarkan perubahan sikap dan perilaku siswa dan guru dalam proses pembelajaran menulis puisi melalui teknik akrostik dan mengacu pada data nontes yang berupa observasi dan wawancara. Teknik ini juga digunakan untuk menganalisis hasil unjuk kerja menulis puisi dan evaluasi tes siswa di setiap siklus.

\section{Hasil dan Pembahasan}

Hasil dan pembahasan diuraikan dalam tiga bagian, yaitu: (1) pelaksanaan tindakan, (2) peningkatan proses pembelajaran melalui teknik akrostik, dan (3) hasil pembelajaran menulis puisi melalui teknik akrostik. 


\section{Pelaksanaan Tindakan}

Terdapat empat fase dalam setiap siklus pada penelitian ini. Pada fase-fase tersebut, dilaksanakan juga perubahan-perubahan yang ingin dicapai. Berikut adalah paparan pelaksanaan penelitian yang dilakukan.

\section{Perencanaan}

Pada tahap perencanaan, dilaksanakan lima kegiatan, meliputi: (1) membuat rencana pelaksanaan pembelajaran (RPP) untuk setiap pertemuan; (2) mempersiapkan sumber dan bahan yang akan diberikan; (3) mengembangkan bahan ajar sesuai materi yang akan diajarkan dengan menggunakan teknik akrostik; (4) membuat lembar obsevasi untuk siswa dan guru selama proses pembelajaran berlangsung; dan (5) membuat dan menyusun butir-butir soal atau format evaluasi untuk tes pada siklus pertama.

\section{Pelaksanaan}

Pada tahap ini guru melaksanakan langkah-langkah pembelajaran yang telah direncanakan dalam rencana pelaksanaan proses pembelajaran (RPP), (1) menyampaikan tujuan menulis puisi menggunakan teknik akrostik dan mengulas materi yang telah dipelajari pada pertemuan sebelumnya, (2) siswa diajak untuk menganalisis unsur pembangun puisi; (3) guru melakukan tanya jawab tentang materi teknik akrostik; (4) guru mengarahkan siswa untuk menentukan judul puisi yang didasarkan pada pengamatan terhadap bendabenda dan peristiwa yang ada di sekitar siswa.

\section{Observasi}

Observasi dilakukan untuk mengamati dapak atau hasil yang dikenakan kepada terhadap siswa. Observasi dilaksanakan terhadap aktivitas guru dan siswa dengan paduan lembar observasi yang telah dipersiapkan. Peneliti melakukan pengamatan dan mencatat semua proses yang terjadi dalam tindakan pembelajaran, diskusi antara guru dan peneliti pelaksanaan tindakan yang akan dilakukan, mencatat semua kelemahan yang terlihat dari tindakan maupun respon siswa yang berbeda dengan yang diharapkan. Di samping itu, peneliti juga menganalisis tindakan-tindakan yang telah dilaksanakan.

\section{Refleksi}

Refleksi merupakan langkah terakhir pada penelitian ini. Kegiatan yang dilakukan pada langkah ini, yakni (1) melakukan evaluasi terhadap tindakan yang telah dilakukan dan berdiskusi bersama guru mengenai tindakan yang telah diberikan; (2) jika masih terdapat masalah-masalah pada tindakan dan hasil yang 
dicapai pada siklus I (pertama) belum sesuai indikator dan target yang direncanakan maka akan dimusyawarahkan bersama guru alternatif pemecahannya dan selan-jutnya direncanakan tindakan berikutnya di siklus II. Tahapan pelaksanaan di siklus II secara umum mengulang tahapan-tahapan yang sama dengan siklus I, namun dengan perbaikan-perbaikan yang disesuaikan dengan hasil evaluasi pelaksanaan di siklus I dan berdasarkan diskusi bersama guru. Peningkatan Proses Pembelajaran Menulis Puisi melalui Teknik Akrostik Berdasarkan pengamatan dan studi pendahuluan yang telah dilakukan peneliti sebelumya, tampak bahwa masih terdapat hal-hal yang harus diperbaiki untuk meningkatkan kualitas pembelajaran. Rumusan tujuan pembelajaran yang hendak dicapai ialah melalui pembelajaran ialah (1) memhami pengertian puisi (2) memahami unsur pembangun puisi (unsur fisik dan unsur batin, dan (3) menemukan sebuah ide sebagai bahan untuk menulis puisi dengan memperhatikan unsur pembangunnya. Pada aspek psikomotorik, diharapkan siswa dapat menulis puisi dengan pilihan diksi yang tepat. Dari aspek afektif, (1) siswa terlibat aktif dalam pembelajaran dengan menunjukkan sikap aktif, kreatif, percaya diri, dan apresiatif, (2) siswa terlibat aktif dalam pembelajaran yang ditunjukan dengan keaktifan dalam berkomunikasi.Pada pelaksanaan tindakan siklus I, kegiatan berpedoman dengan langkah-langkah menulis puisi dengan teknik akrostik, yakni (1) penggalian ide, (2) penentuan ide, dan (3) penyajian. Metode pembelajaran yang digunakan dalam proses pembelajaran ialah ceramah, tanya jawab, dan penugasan. Kegiatan pembelajaran dilalui dengan tiga tahap, yakni pendahuluan, inti, dan penutup.

Berdasarkan refleksi yang telah dilakukan pada siklus I, masih ditemukan hal-hal yang menjadi sebab berjalannya proses pembelajaran kurang efektif, di antaranya: (1) guru masih kurang dalam melakukan pendampingan ketika siswa melakukan penggalian ide, (2) guru masih mendominasi pembelajaran, sehingga siswa kurang memiliki kesempatan untuk mengungkapkan ide maupun tanggapan dalam proses pembelajaran, (3) sebagian siswa masih kurang percaya diri dalam mengungkapkan ide maupun gagasan yang dimiliki, (4) masih terdapat siswa yang meniru puisi dari siswa yang lainnya, dan (5) pada kegiatan menulis puisi, siswa masih kebingungan dalam melalui langkah-langkah menulis puisi dengan teknik akrostik. Selain itu, guru juga belum lengkap dalam menempuh langkah-langkah pembelajaran yang harusnya dilakukan. Karena adanya kendala tersebut, menyebabkan indikator keberhasilan belum tercapai pada siklus I, sehingga penelitian dilajutkan pada siklus II. Jika dipersentasekan ketuntasan belajar siswa pada siklus I sebesar $67,7 \%$. 
Tabel 1. Perubahan Data Pelaksanaan Pembelajaran Siklus I Ke Siklus II

\begin{tabular}{cc}
\hline Siklus & Ketuntasan aktivitas belajar siswa \\
\hline I & $67,7 \%$ \\
II & $80,05 \%$ \\
Peningkatan & $12,75 \%$ \\
Proses & \\
\hline
\end{tabular}

Setelah melakukan evaluasi terhadap kekurangan yang ada pada siklus I, terjadi peningkatan proses pembelajaran yang ada pada siklus II. Hal ini terlihat dari hasil observasi yang dilakukan oleh peneliti terhadap guru dan siswa. Langkah langkah yang tidak dilakukan guru pada siklus I telah lengkap dilalui pada siklus II ini. Nampak guru juga sudah melakuka pendampingan terhadap siswa pada tiap langkah pembelajaran yang dilalui. Pada siklus II ini siswa juga sudah nampak lebih percaya diri dan lebih aktif dan menunjukkan sikap saling menghargai. Perubahan tersebut dapat dilihat pada tabel berikut.

\section{Peningkatan Hasil Pembelajaran Menulis Puisi melalui Teknik Akrostik}

Data hasil dari siklus I dan siklus II menunjukkan bahwa hasil tes kemampuan menulis puisi keempat puluh siswa setelah pembelajaran mengalami peningkatan. Hasil analisis kemampuan menulis puisi siswa dilihat dari keterkaitan objek dengan isi puisi, pilihan kata atau diksi, dan pengimajian. Penggunaan teknik akrostik ternyata dapat meningkatan hasil pembelajaran menulis puisi. Peningkatan tersebut dapat dilihat dari tabel berikut.

Tabel 2. Perubahan Persentase Kuantitatif Perolehan Nilai Hasil Menulis Puisi

\begin{tabular}{ccc}
\hline \multicolumn{2}{c}{ Persentase perolehan nilai } & Siklus \\
\cline { 1 - 2 } Nilai 70 ke atas & Nilai di bawah 70 & \\
$98 \%$ & $32 \%$ & $80,05 \%$ \\
$92 \%$ & $8 \%$ & $12,75 \%$ \\
\hline
\end{tabular}

Dari tabel di atas, tampak nilai hasil belajar siswa meningkat secara signifikan. Jumlah siswa yang memperoleh nilai kurang dari 70 berkurang 24\%. Dilihat dari hasil evaluasi tes kognitif siswa pada siklus I, siswa telah mencapai indikator yang ditetapkan oleh peneliti sehingga penelitian tidak dilanjutkan kepada siklus selanjutnya. Hal ini dapat kita lihat pada tabel berikut. 
Tabel 3. Perolehan Nilai Hasil Evaluasi Tes Siswa

\begin{tabular}{lc}
\hline \multicolumn{1}{c}{ Perolehan nilai } & Persentase \\
\hline Nilai 70 ke atas & $79 \%$ \\
Nilai di bawah 70 & $21 \%$ \\
Jumlah & $100 \%$ \\
\hline
\end{tabular}

Berdasarkan tabel tersebut, hasil perolehan nilai secara kuantitatif dapat dilihat bahwa siswa yang mendapatkan nilai di bawah 70 sebanyak $21 \%$. Kemudian siswa yang mendapat nilai lebih dari 70 sebanyak 79\%. Dari hasil tersebut sudah menunjukkan siswa telah mencapai indikator keberhasilan yang telah ditetapkan, yakni 75\% atau lebih siswa telah mencapai ketuntasan minimal (KKM) 70. Berdasarkan perolehan tersebut, maka sikklus dihentikan.

\section{Pembahasan}

Paparan hasil penelitian menunjukkan peningkatan baik dalam proses maupun hasil pembelajaran dari siklus II. Peningkatan tersebut dicapai karena penerapan teknik akrostik ketika menulis puisi. Guru juga telah melakukan perbaikan kualitas diri dalam melakukan pengajaran, hal ini ditunjukkan dengan optimalnya pendampingan guru terhadap siswa dalam menyelesaikan langkahlangkah pembelajaran. Guru juga menciptakan suasana kelas yang komunikatif dengan lebih banyak memberikan ruang kepada siswa untuk mengungkapkan ide dan gagasan yang mereka miliki. Efek yang ditimbulkan dari beberapa hal tersebut ialah siswa lebih percaya diri dan mendapatkan hasil pembelajaran menulis puisi dengan maksimal.

Dilihat dari aspek sikap siswa, pada siklus II nampak peningkatan pada sikap percaya diri, bekerja sama, dan saling menghargai yang sebelumnya belum muncul pada siklus I. Pada aspek kongnitif, siswa relatif menguasai materi pembelajaran. Hal ini ditunjukkan dengan hasil nilai yang seluruhnya memenuhi KKM yang telah ditentukan. Meskipun demikian pengulangan materi ini tetap penting untuk meningkatkan pengetahuan siswa berkaitan dengan puisi. Pentingnya penguasaan terhadap teori dikemukakan oleh Asri. Berdasarkan penelitian Asri, penguasaan materi siswa sangatlah berkaitan erat dengan keterampilan menulis puisi.?

Ketidakberhasilan pencapaian KKM pada sikulus I disebabkan karena proses belajar kurang efektif. Hal ini berdampak pada proses dan hasil

${ }^{9}$ Asri, A. 2017. Korelasi Penguasaan Teori Puisi dengan Keterampilan Menulis Puisi Mahasiswa Program Studi Pendidikan Bahasa dan Sastra Indonesia Fakultas Bahasa san Sastra Univer-sita Negeri Makassar Angkatan 2015. Retorika, 10 (1): h. 6 
pembelajaran siswa yang belum mencapai ketuntasan minimal (KKM). Berdasalkan hal tersebut, dapat disimpulkan bahwa kefektifan proses pembelajaran berpengaruh pada proses dan hasil pembelajaran. Proses pembelajaran yang menggunakan model, metode, dan tentunya teknik yang tepat dapat berdampak pada hasil menulis siswa yang lebih baik. Hal ini serupa dengan penelitian yang dilakukan oleh Fitri yang menunjukkan hasil yang berbeda pada siklus dua setelah memaksimalkan pembelajaran. Dengan mengubah suasana positif dalam pembelajaran maka siswa akan lebih termotivasi untuk mengikuti langkah-langkah pembelajaran yang telah direncanakan oleh guru. ${ }^{10}$

Hasil penelitian pada siklus II menunjukkan hasil belajar siswa mengalami peningkatan yang signifikan. Hal tersebut disebabkan penerapan teknik akrostik disertai perbaikan-perbaikan proses pembelajaran yang dilakukan oleh guru. Hasil tersebut dapat disimpulkan sebagai keunggulan teknik akrostik dalam menulis puisi. Berdasarkan hasil penelitian, keunggulan teknik akrostik adalah (1) memberikan kemudahan bagi siswa untuk menggali ide untuk menulis puisi; (2) memberikan kemudahan bagi siswa untuk mengembangkan ide tersebut menjadi larik-larik puisi dengan pemiliha diksi yang tepat; (3) judul yang kemudian disusun secara vertikan membuat para pembaca mudah memaknai puisi yang dibuat dengan teknik ini. Keunggulan tersebut diungkapkan juga oleh Frye dalam penelitannya yang me-nyatakan bahwa teknik akrostik ini adalah teknik yang sederhana dan memudahkan siswa dalam menulis puisi. Kemudahan itu mencakup mencari dan mengembangkan ide. ${ }^{11}$

Selain penerapan teknik akrostik tersebut, guru juga melakukan tindakntindakan yang dijadikan strategi dalam peningkatan keberhasilan menulis puisi. Hal ini juga membuat penelitian ini berbeda dengan penelitian terdahulu yang dilakukan oleh Herawati dan Al-Hajj meski hasil penelitian ini sejalan dengan keduanya. Hasil penelitian ekperimen yang dilakukan oleh Harwati menunjukkan hasil bahwa kelas yang menggunakan teknik akrostik dalam menulis puisi mampu memberikan hasil lebih baik dari pada kelas yang tidak menggunakan teknik tersebut. Begitu pula degan penelitian yang dila-kukan oleh Al-Hajj yang juga menunjukkan hasil yang positif dengan meningkatnya

\footnotetext{
${ }^{10}$ Fitri, S. 2017. Peningkatan Kemampuan Menulis Puisi dengan Menggunakan Metode Kooperatif Tipe Think Pair Share (Berpikir, Berpasangan, Dan Berbagi) pada Siswa Kelas VIII SMP Negeri 4 Bulukumba. Retorika, 10 (1): 53.

${ }^{11}$ Frye, E. M., W. Trathen, \& B. Schlagal.. Extending Acrostic Poetry Into Content Learning: A Scaffolding Framework. (The Reading Teacher, 63 (7), 2010) h. 591-595.
} 
kemampuan siswa. ${ }^{12}$ Pada penelitian yang dilakukan Al-Hajj, ia menekankan pada pentingnya memberikan motivasi dan bimbingan kepada siswa secara terus menerus. ${ }^{13}$ hal ini akan menjadikan salah satu faktor penting dalam tercapainya tujuan pembelajaran. Hal yang tak kalah penting ialah menggiring para siswa sampai ke zona alfa. Ketika pada kondisi demikianlah kondisi kelas akan kondusif. Zona alfa adalah kondisi terbaik untuk belajar siswa. Zona alfa adalah kondisi rileks dan menyenangkan sehingga dapat dibutuhkan oleh siswa untuk mulai menerima pembelajaran pada kondisi ini. Hal ini akan memudahkan dan membuat mereka lebih siap untuk memasuki pelajar-an. Penggunaan yel-yel dan permainan dalam kelas juga membuat siswa lebih rileks dan pembelajaran berlangsung lebih menyenangkan. Selain itu, penggunaan mading di dalam peneliti-an ini sebagai salah satu alat untuk memberikan reward atau penghargaan terhadap hasil karya siswa juga sangat baik dalam meningkatkan motivasi belajar siswa.

Strategi-strategi yang dilakukan guru di atas akan menjadikan kelas lebih kondusif. Frye sendiri menjelaskan bahwa mempelajari puisi dengan menggunakan teknik akrostik yang dikombinasikan dengan model mengajar guru akan menciptakan suatu jembatan pembantu untuk siswa. ${ }^{14}$ Dengan demikian, dapat disimpulkan bahwa penerapan teknik akorstik yang didipadukan dengan model atau startegi-strategi yang menarik dapat mengefektifkan dan memaksimalkan pembelajaran.

Sekalian memiliki keunggulan, teknik akrostik juga memiliki kelemahan. Berdasarkan temuan peneliti, terdapat dau kelemahan teknik akrostik, yaitu (1) puisi yang dihasilkan terlalu sederhana dan terlalu kaku; (2) membutuhkan sebuah keahlian untuk menghubungkan dan merangkia kata sehingga memiliki puisi yang dibuat memiliki makna yang utuh dan padu; (3) membutuhkan perbendaharaan kata yang banyak agar siswa mampu menemukan diksi yang tepat untuk membuat puisi dari huruf yang dijajar secara vertikal. Kelemahankelemahan tersebut juga ditemukan Frye ia mengatakan bahwa penggunaan teknik ak-rostik ini masih memerlukan strategi yang bisa membantu siswa untuk mengembangkan bahasa puisi menjadi lebih memperhatikan keindahan rasa

\footnotetext{
${ }^{12}$ Herawati. 2010. Penerapan Penggunaan Strategi Akrostik dalam Pembelajaran Menulis Puisi Siswa Kelas VIII SMP Negeri 1 Bontomatene Kabupaten Selayar. Skripsi. Makassar: FBS UNM.

${ }^{13}$ Al-Hajj, I. 2005. Strategi Menulis Puisi Akrostik se-bagai Upaya Meningkatkan Keterampilan Menulis Puisi Siswa Kelas VII SMPN 2 Kendari. Tesis. Makassar: UNM.

${ }^{14}$ Frye, E. M., W. Trathen, \& B. Schlagal, Extending Acrostic Poetry Into Content Learning: A Scaffolding Framework", (The Reading Teacher, 63 (7): 2010) h. 591
} 
atau lebih puitis. ${ }^{15}$ Oleh karena itu, pemanfaatan teknik ini perlu dipadukan dengan teknik lain agar hasil belajar lebih optimal.

\section{Penutup}

Berdasarkan hasil belajar siswa, baik secara proses maupun hasil, dapat disimpulkan bahwa penerapan teknik akrostik pada mata pelajaran bahasa indonesai khususnya untuk meningkatkan kemampuan menulis puisi sangat efektif. Hal ini sesuai dengan hasil penelitian yang dilaksanakan pada siklus I dan siklus II yang menunjukkan bahwa perolehan skor proses dan hasil pembelajaran meningkat. Teknik akrostik yang digunakan dalam penelitian ini akan lebih efektif diterapkan dalam pembelajaran apabila dilakukan dengan mengintegrasikan pengalaman belajar siswa di sekolah. Mereka dapat menggunakan berbagai topik untuk menulis puisi dengan mensintesis pengalaman dan informasi yang mereka ketahui. Untuk kedepannya, penggunaan teknik ini dapat dipadukan dengan model, media, maupun teknik pembelajaran yang lain agar hasil belajara siswa baik secara hasil maupun proses dapat terus meningkat.

\section{Ucapan Terima Kasih}

Ucapan terima kasih disampaikan penulis kepada SMA Negeri 7 Malang karena sudah memberikan kesempatan untuk melaksanakan peneitian dan ikut andil dalam proses pembelajaran. Uncapan terima kasih peneliti ucapkan kepada Program Stiudi PPG Universitas Muhammadyah Malang yang telah memberikan wadah untuk memperdalam wawasan di bidang pendidikan.

\section{Daftar Pustaka}

Al-Hajj, I. 2005. Strategi Menulis Puisi Akrostik se-bagai Upaya Meningkatkan Keterampilan Menulis Puisi Siswa Kelas VII SMPN 2 Kendari. Tesis. Makassar: UNM.

Atmazaki. 2013. Mengungkap Masa Depan: Inovasi Pembelajaran Bahasa Indonesia dalam Konteks Pengembangan Karakter Cerdas. Makalah. Padang: UNP.

Asri, A. 2017. Korelasi Penguasaan Teori Puisi dengan Keterampilan Menulis Puisi Mahasiswa Program Studi Pendidikan Bahasa dan Sastra

${ }^{15}$ Frye, E. M., W. Trathen, \& B. Schlagal, Extending Acrostic Poetry Into Content Learning: A Scaffolding Framework, (The Reading Teacher, 63 (7), 2010) h. 591-595. 
Indonesia Fakultas Bahasa dan Sastra Universitas Negeri Makassar Angkatan 2015. Retorika, 10 (1): 1-7.

Bahtiar. 2019. Ahmad dkk. Khazanah Bahasa: Memaknai Bahasa Indonesia dengan Baik dan Benar. Bogor: In Media

Chaer, Abdul. 2012. Linguistik Umum. Jakarta: Rineka Cipta

Fitri, S. 2017. Peningkatan Kemampuan Menulis Puisi dengan Menggunakan Metode Kooperatif Tipe Think Pair Share (Berpikir, Berpasangan, Dan Berbagi) pada Siswa Kelas VIII SMP Negeri 4 Bulukumba. Retorika, 10 (1): 49-55.

Frye, E. M., W. Trathen, \& B. Schlagal. 2010. Extending Acrostic Poetry Into Content Learning: A Scaffolding Framework. The Reading Teacher, 63 (7): 591-595.

Herawati. 2010. Penerapan Penggunaan Strategi Akrostik dalam Pembelajaran Menulis Puisi Siswa Kelas VIII SMP Negeri 1 Bontomatene Kabupaten Selayar. Skripsi. Makassar: FBS UNM.

Hudaa, Syihaabul. "Optimalisasi Bahasa: Penggunaan Bahasa yang Baik, Logis, dan Santun di Media Massa, "Jurnal Dialektika, Vol. 5, No. 1.

Nurgiyantoro, B. \& A. Efendi. 2013. Prioritas Penen-tuan Nilai Pendidikan Karakter dalam Pembelajaran Sastra Remaj. Cakrawala Pendidikan, 32 (3): 382-393.

Testy Ariance Loren, Fabio. "Pemakaian Media Pembelajaran Keterampilan Menyimak dalam Pembelajaran Bahasa Indonesia bagi Penutur Asing," Lingua Didaktika: Jurnal Bahasa dan Pembelajaran Bahasa, Vol. 11, No.1. 